\title{
Biotechnological Potential of Agro Residues for Economical Production of Thermoalkali-Stable Pectinase by Bacillus pumilus dcsr 1 by Solid-State Fermentation and Its Efficacy in the Treatment of Ramie Fibres
}

\author{
Deepak Chand Sharma ${ }^{1}$ and T. Satyanarayana ${ }^{2}$ \\ ${ }^{1}$ Department of Microbiology, Chaudhary Charan Singh University, Meerut 250 004, India \\ ${ }^{2}$ Department of Microbiology, University of Delhi South Campus, Benito Juarez Road, New Delhi 110 021, India
}

Correspondence should be addressed to T. Satyanarayana, tsnarayana@gmail.com

Received 16 April 2012; Revised 26 June 2012; Accepted 26 June 2012

Academic Editor: Jose M. Guisan

Copyright (c) 2012 D. C. Sharma and T. Satyanarayana. This is an open access article distributed under the Creative Commons Attribution License, which permits unrestricted use, distribution, and reproduction in any medium, provided the original work is properly cited.

\begin{abstract}
The production of a thermostable and highly alkaline pectinase by Bacillus pumilus dcsr 1 was optimized in solid-state fermentation (SSF) and the impact of various treatments (chemical, enzymatic, and in combination) on the quality of ramie fibres was investigated. Maximum enzyme titer $\left(348.0 \pm 11.8 \mathrm{Ug}^{-1} \mathrm{DBB}\right)$ in SSF was attained, when a mixture of agro-residues (sesame oilseed cake, wheat bran, and citrus pectin, $1: 1: 0.01)$ was moistened with mineral salt solution $\left(a_{w} 0.92\right.$, pH 9.0) at a substrateto-moistening agent ratio of $1: 2.5$ and inoculated with $25 \%$ of $24 \mathrm{~h}$ old inoculum, in $144 \mathrm{~h}$ at $40^{\circ} \mathrm{C}$. Parametric optimization in SSF resulted in 1.7-fold enhancement in the enzyme production as compared to that recorded in unoptimized conditions. A 14.2-fold higher enzyme production was attained in SSF as compared to that in submerged fermentation (SmF). The treatment with the enzyme significantly improved tensile strength and Young's modulus, reduction in brittleness, redness and yellowness, and increase in the strength and brightness of ramie fibres.
\end{abstract}

\section{Introduction}

Solid-state fermentation (SSF) takes place in absence or near absence of free flowing water [1] and is of special economic interest for countries having abundant biomass and agroindustrial residues. The solid substrates act as source of carbon, nitrogen, minerals, and growth factors and have the capacity to absorb water in order to meet the growth requirements of microbes. The possibility of using SSF for pectinase production has been shown using different agroindustrial residues such as wheat bran [2-4], apple pomace $[5,6]$, lemon and orange peel [7-9], sugar cane bagasse [10], tomato pomace [11], and sugar beet pulp [12]. Very few detailed investigations have, however, been conducted on the production of alkaline and thermostable pectinases in SSF using bacterial strains [2, 13-16].

Pectinases optimally active at acidic $\mathrm{pH}$ find extensive applications in the extraction, clarification, and liquefaction of fruit juices and wines $[17,18]$, while alkaline pectinases find applications in textile industry for retting of plant fibres, manufacturing of cotton fabrics, and enzymatic polishing of jute/cotton-blended fabrics, in paper industry to solve the retention problems in mechanical pulp bleaching, in the treatment of pulp and paper mill effluents, and for improving the quality of black tea $[15,19-24]$. Ramie (china grass) fibre is considered one of the longest, strongest, and silkiest plant fibres known [25]. The cellulose fibres of ramie are also arranged in bundles parallel to the longitudinal axis of the stem and are embedded in a pectic polysaccharide network as present in bast fibre plants [26]. The gummy material present on the surface of fibre should be removed without causing damage to the structure of fibre to maintain its flexibility. Development of high brittleness is a major disadvantage of the fibre for the application in textile industry [25], and the condition is caused by the nonspecific treatment with chemicals or with crude enzyme preparations having 
cellulase. Hence, in this investigation an attempt has been made to optimize various physical and chemical parameters to produce elevated levels of thermo-alkali stable pectinase using agriculture residues in SSF by the alkali tolerant Bacillus pumilus dcsr1 (GenBank accession AY426610). Thecost effective production of this valuable enzyme for the processing of ramie fibres [15] will enhance its applicability in the development of green technology. The effect of various treatments on the physical properties of ramie fibre is also discussed.

\section{Materials and Methods}

2.1. Source of the Strain and Its Identification. The bacterial strain was isolated from a soil sample collected from Rohtak, Haryana (India), maintained on nutrient agar slants at $4^{\circ} \mathrm{C}$, and also stored as glycerol stocks at $-20^{\circ} \mathrm{C}$. The strain was identified as B. pumilus dcsr1 (99\% homology) based on $16 \mathrm{~S}$ rDNA sequence analysis (GenBank accession number AY426610).

2.2. Pretreatment of Solid Substrates. Agro-residues used in this investigation were collected from local market and washed with water (to remove the dirt and soluble impurities), air-dried, and ground to uniform size.

2.3. Production of Alkaline Pectinase in Wheat Bran. The fermentation was carried out in $250 \mathrm{~mL}$ Erlenmeyer flasks containing $5 \mathrm{~g}$ of pretreated wheat bran moistened with $12.5 \mathrm{~mL}$ of distilled water and autoclaved at $121^{\circ} \mathrm{C}(15 \mathrm{Lb}$ psi) for $15 \mathrm{~min}$. The flasks were cooled and inoculated with $20 \%$ $(\mathrm{w} / \mathrm{v})$ of the bacterial culture $\left(\mathrm{CFU} \approx 1.58 \times 10^{8} \mathrm{~mL}^{-1}\right)$ cultivated for $24 \mathrm{~h}$ in lactose-pectin-yeast extract broth [gL ${ }^{-1}$ : lactose 1.90 , citrus pectin 3.50 , yeast extract 1.00 , casein $1.8, \mathrm{~K}_{2} \mathrm{HPO}_{4} 1.00, \mathrm{MgSO}_{4} \cdot 7 \mathrm{H}_{2} \mathrm{O}$ 2.50, $\mathrm{Na}_{2} \mathrm{HPO}_{4}$ $5.00,2 \mathrm{~mL}$ micronutrient solution, and $\mathrm{pH} 8.0$ [15]]. The inoculum was mixed thoroughly by gently tapping the bottom of the flasks and incubated in a humidified chamber (YORCO Pvt. Ltd., New Delhi, India) maintained at $80 \%$ relative humidity (RH) and $40^{\circ} \mathrm{C}$ for $96 \mathrm{~h}$. Periodically the contents of the flasks were mixed by gentle tapping against the palm.

2.4. Observation of Bacterial Growth on Wheat Bran. Fortyeight-hour-old bacterial growth on wheat bran was fixed in glutaraldehyde $(2.5 \%$, for $4 \mathrm{~h})$ and then washed with phosphate buffer. The fixed samples were dehydrated in ascending grades of alcohol $(30 \%, 50 \%, 70 \%, 80 \%, 90 \%$, and $100 \%$ ) for $30 \mathrm{~min}$, dried in 1,1,1,3,3,3-hexamethyldisilazane (HMDS) and gold film (thickness $20-25 \mathrm{~nm}$ ) was created with the help of agar sputter coater. The bacterial growth was examined under scanning electron microscope (Leo 435 UP, Cambridge, UK).

2.5. Extraction of the Enzyme from the Fermented Substrate. After $96 \mathrm{~h}$, contents of the flasks were extracted twice with $25 \mathrm{~mL}$ of buffer ( $0.01 \mathrm{M}$ sodium phosphate buffer, $\mathrm{pH} 7.0)$ by constant shaking for $1 \mathrm{~h}$ in a rotary shaker at $200 \mathrm{rpm}$. The extract was squeezed through muslin cloth and centrifuged at $10,000 \mathrm{rpm}$ for $20 \mathrm{~min}$ at $4^{\circ} \mathrm{C}$. The cell-free supernatant thus obtained was used as the source of extracellular alkaline pectinase. The fermented substrate was dried to constant weight at $80^{\circ} \mathrm{C}$ for determining dry weight of the bacterial bran. The enzyme titre is expressed as units gram $^{-1}$ dry bacterial bran $\left(\mathrm{Ug}^{-1} \mathrm{DBB}\right)$.

2.6. Alkaline Pectinase Assay. Alkaline pectinase in the cellfree culture filtrate was assayed according to Sharma and Satyanarayana [15]. One unit of pectinase is defined as the amount of enzyme that liberates $1 \mu$ mole reducing sugars as $\mathrm{D}$-galacturonic acid $\mathrm{min}^{-1}$ under the assay conditions.

\subsection{Effect of Various Agro Residues on Alkaline Pectinase} Production. The bacterium was grown in Erlenmeyer flasks $(250 \mathrm{~mL})$ containing $5 \mathrm{~g}$ of different pre-treated agroresidues (citrus peel, pomegranate peel, citrus peel powder, pineapple pulp, spent tea leaves, sunflower leaf, cotton oilseed cake, mustard oilseed cake, sesame oilseed cake, wheat straw, wheat bran, sun hemp stalks, sunflower stalks, sunflower, sugarcane bagasse, ramie fibre, sun hemp fibre and rice straw). The bacterial strain was also cultivated in flasks containing different quantities $(2.5,5,10,15,20 \mathrm{~g})$ and combinations of solid substrates (wheat bran, sesame oilseed cake, mustard oilseed cake, and citrus peel).

\subsection{Effect of Various Moistening Agents on Alkaline Pectinase} Production. For selecting the best moistening agent, mixed solid substrate (wheat bran, sesame oilseed cake and citrus pectin in $1: 1: 0.5$ ratio) was moistened with different salt solutions (SS) $\left(\mathrm{gL}^{-1}\right.$ : SS1. $\left(\mathrm{NH}_{4}\right)_{2} \mathrm{SO}_{4} 4.00, \mathrm{KH}_{2} \mathrm{PO}_{4}$ 10.00, $\mathrm{CaCl}_{2}$ 0.30, $\mathrm{FeSO}_{4}$ 0.30, $\mathrm{MgSO}_{4}$ 0.30; SS2. $\left(\mathrm{NH}_{4}\right)_{2} \mathrm{SO}_{4}$ 0.40, $\mathrm{KH}_{2} \mathrm{PO}_{4}$ 2.10, $\mathrm{CaCl}_{2}$ 0.30, $\mathrm{FeSO}_{4} 0.11, \mathrm{MnSO}_{4}$ 0.30; SS3. $\mathrm{CaCl}_{2}$ 0.10, $\mathrm{MgSO}_{4} \cdot 7 \mathrm{H}_{2} \mathrm{O}$ 0.50, $\mathrm{FeSO}_{4}$ 0.10; SS4. $\mathrm{NH}_{4} \mathrm{NO}_{3}$ 2.00, $\mathrm{K}_{2} \mathrm{HPO}_{4}$ 6.00, KCl 0.50, $\mathrm{MgSO}_{4}$ 0.50; SS5. $\mathrm{K}_{2} \mathrm{HPO}_{4}$ 0.10, $\left(\mathrm{NH}_{4}\right)_{2} \mathrm{H}_{2} \mathrm{PO}_{4} 1.00, \mathrm{MgSO}_{4} 0.50, \mathrm{CaCl}_{2} \quad 0.10, \mathrm{FeSO}_{4}$ 0.10, $\mathrm{MnSO}_{4}$ 0.10; SS6. $\mathrm{Na}_{2} \mathrm{HPO}_{4}$ 11.00, $\mathrm{NaH}_{2} \mathrm{PO}_{4}$ 6.00, $\mathrm{KCl} 3.00, \mathrm{MgSO}_{4}$ 0.10; SS7. $\mathrm{KH}_{2} \mathrm{PO}_{4} 2.40, \mathrm{MgSO}_{4} \cdot 7 \mathrm{H}_{2} \mathrm{O}$ $0.50, \mathrm{CaCl}_{2} \cdot 2 \mathrm{H}_{2} \mathrm{O} 0.10$ ), SS8. distilled water, SS9. phosphate buffer, and SS10. tap water were used $(12.5 \mathrm{~mL} / 5 \mathrm{~g}$ of solid substrate). The $\mathrm{pH}$ of the salt solutions was adjusted to 8.0 using $1 \mathrm{~N} \mathrm{HCl} / \mathrm{NaOH}$.

\subsection{Effect of Various Physical Parameters on Alkaline Pectinase} Production. The ratio of the solid substrate $(\mathrm{g})$ to moistening agent $(\mathrm{mL})$ was varied $(1: 1,1: 2,1: 2.5,1: 3,1: 4$, and $1: 5)$. The inoculum age was optimized by inoculating the substrate with bacterial inoculum grown for 12, 24, 36, 48 $25,60,72$, and $84 \mathrm{~h}$, while the optimum inoculum size was determined by inoculating the substrate with the desired volume of the bacterial culture. To study the effect of $\mathrm{pH}$ on enzyme production, the bacterial strain was cultivated on the substrate moistened with salt solutions of varied $\mathrm{pH}(0.1 \mathrm{M}$ citrate buffer for $\mathrm{pH} 4 \& 5.0 ; 0.1 \mathrm{M}$ phosphate buffer for pH 6.0 to 8.0; $0.1 \mathrm{M}$ glycine- $\mathrm{NaOH}$ buffer for $\mathrm{pH}$ 9.0; CAPS buffer (N-cyclohexyl-3-aminopropanesulfonic acid) for $\mathrm{pH}$ $10,10.5 \& 11$. The effect of temperature was assessed by 


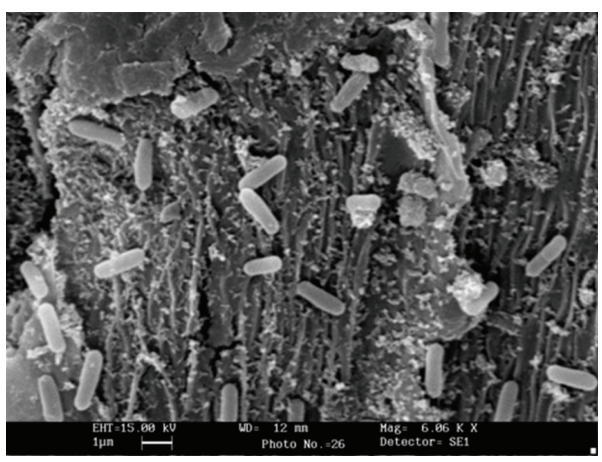

FIGURE 1: Scanning electron micrograph of fermented solid substrate (wheat bran) showing bacterial cells.

incubating inoculated flasks at different temperatures (30, $35,40,45$, and $50^{\circ} \mathrm{C}$ ).

2.10. Effect of Water Activity $\left(a_{w}\right)$ on Alkaline Pectinase Production. B. pumilus was cultivated in flasks containing solid substrate moistened with salt solution 4 with glycerol for attaining different $a_{w}$ values according to Grajek and Gervais [27].

2.11. Treatment of Ramie Fibre and Evaluating the Properties of the Treated Fibres. The ramie fibres were treated according to Sharma and Satyanarayana [15], and the physical properties of the fibres were assessed at National Physical Laboratory (NPL, Delhi, India). Tensile strength, strain, and Young's Modulus were determined by universal testing machine (Instron, USA). The color coordinates of the sample were measured by gonio spectrophotometer (Zeiss, Germany). The source used for illumination was a pulsed xenon lamp having a spectral distribution of a $\mathrm{D}_{65}$ illuminant. The measurements were made using a $10^{\circ}$ standard observer in the spectral range $300-720 \mathrm{~nm}$. The CIELAB color parameters $L^{*}$ (brightness), $a^{*}$ (redness), and $b^{*}$ (yellowness) were also measured.

\section{Results and Discussion}

Solid-state fermentation (SSF) has great potential for the development of several bioprocesses and products because of enhanced productivity and prospects of using a wide range of agro-industrial residues as substrates [28, 29]. Efforts have been made to exploit filamentous fungi in SSF for the production of various products, and further attempts are being made to explore the possibility of using bacterial strains in SSF systems $[1,30]$. The direct observation of the microbe in solid substrate remains a difficulty in all studies. Scanning electron microscopy (SEM) of the fermented solid substrate revealed luxuriant bacterial growth on wheat bran particles that confirmed amenability of B. pumilus dcsr 1 to SSF (Figure 1) like some other Bacillus spp. [31]. Among different agro-residues tested (Table 1), sesame oilseed cake supported high pectinase production by B. pumilus $(210.22 \pm$ $\left.8.08 \mathrm{Ug}^{-1} \mathrm{DBB}\right)$. This may be due to the fact that along
TABLE 1: Alkaline pectinase production on various agro-residues alone and their combinations.

\begin{tabular}{|c|c|c|}
\hline S. no. & Solid substrates used & $\begin{array}{l}\text { Enzyme production } \\
\left(\mathrm{Ug}^{-1} \mathrm{DBB}\right)\end{array}$ \\
\hline$(1)$ & Wheat straw & $23.17 \pm 2.23$ \\
\hline (2) & Rice husk & $45.09 \pm 5.60$ \\
\hline (3) & Wheat bran & $160.97 \pm 3.11$ \\
\hline$(4)$ & Sesame oil seed cake & $210.22 \pm 8.08$ \\
\hline (5) & Mustard oil seed cake & $204.99 \pm 4.22$ \\
\hline (6) & Cotton oil seed cake & $37.09 \pm 7.07$ \\
\hline$(7)$ & Sugarcane bagasse & $27.65 \pm 1.02$ \\
\hline$(8)$ & Pomegranate peel & $72.03 \pm 9.58$ \\
\hline (9) & Pineapple pulp & $140.16 \pm 5.23$ \\
\hline$(10)$ & Sun hemp fibre & $73.18 \pm 6.48$ \\
\hline$(11)$ & Sun hemp stalk & $34.75 \pm 1.55$ \\
\hline$(12)$ & Sunflower seed & $89.24 \pm 5.88$ \\
\hline (13) & Sunflower stalk & $110.34 \pm 0.93$ \\
\hline$(14)$ & Sunflower leaf & $32.51 \pm 0.23$ \\
\hline$(15)$ & Citrus peel & $162.22 \pm 4.28$ \\
\hline$(16)$ & Citrus peel powder & $41.25 \pm 0.92$ \\
\hline$(17)$ & Citrus fruit pulp & $60.66 \pm 2.22$ \\
\hline$(18)$ & Spent tea leaves & $69.99 \pm 0.51$ \\
\hline (19) & Ramie fibres & $116.18 \pm 6.14$ \\
\hline$(20)$ & $\begin{array}{l}\text { Wheat bran }+ \text { sesame oil seed } \\
\text { cake }(1: 1)\end{array}$ & $217.18 \pm 7.18$ \\
\hline$(21)$ & $\begin{array}{l}\text { Wheat bran }+ \text { sesame oil seed } \\
\text { cake }+ \text { Citrus pectin }(1: 1: 0.01)\end{array}$ & $232.12 \pm 12.12$ \\
\hline$(22)$ & Wheat bran + citrus peel $(1: 1)$ & $140.23 \pm 7.23$ \\
\hline$(23)$ & $\begin{array}{l}\text { Wheat bran }+ \text { citrus peel }+ \\
\text { Sesame oil seed cake }(1: 1: 1)\end{array}$ & $59.52 \pm 0.95$ \\
\hline$(24)$ & $\begin{array}{l}\text { Wheat bran }+ \text { mustard oil seed } \\
\text { cake }(1: 1)\end{array}$ & $195.55 \pm 1.55$ \\
\hline
\end{tabular}

with pectinase the bacterial strain also produced lipase and xylanase (data not presented here), which may help in efficient utilization of these solid substrates. A high enzyme titre $\left(232.12 \pm 12.12 \mathrm{Ug}^{-1} \mathrm{DBB}\right)$ was attained when wheat bran was mixed with sesame oil seed cake and citrus pectin (1:1:0.01 ratio) as compared to other combinations (Table 1). Wheat bran is known to be a good solid substrate [32], supplementation of this with other solid substrates led to increase in enzyme yield [17], the enhancement in amylase production was also recorded on supplementing wheat bran with oil seed cakes [28]. Although wheat bran provides good support and availability of water and oxygen for the bacterium, a supplementation with additional carbon and nitrogen source increases the "carrying capacity" of the wheat bran. The bacterium produced high titres of enzyme when granules of citrus peel were used instead of citrus peel powder that may be attributed to the fact that in SSF the solid substrate not only supplies the necessary nutrients to the microorganism but also provides anchorage on the increased surface area with better aeration. Therefore, the particle size and the chemical composition of the substrate 


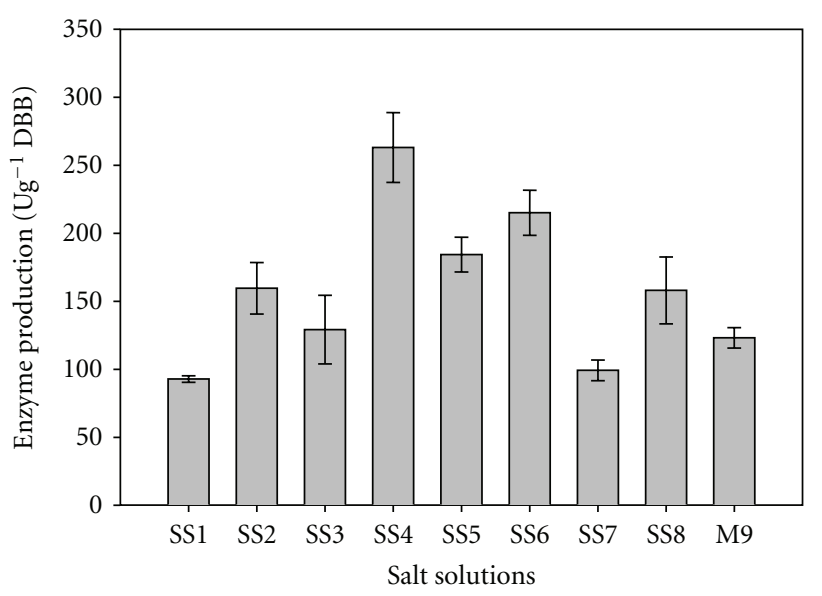

Figure 2: Effect of various salt solutions on alkaline pectinase production in SSF.

are very important $[33,34]$. The low enzyme titre in wheat straw $\left(23.17 \pm 2.23 \mathrm{Ug}^{-1} \mathrm{DBB}\right)$, sugar cane bagasse $(27.65 \pm$ $\left.1.02 \mathrm{Ug}^{-1} \mathrm{DBB}\right)$, rice husk $\left(45.09 \pm 5.60 \mathrm{Ug}^{-1} \mathrm{DBB}\right)$, sun hemp stalk $\left(34.75 \pm 1.55 \mathrm{Ug}^{-1} \mathrm{DBB}\right)$, and sunflower leaf $\left(32.51 \pm 0.23 \mathrm{Ug}^{-1} \mathrm{DBB}\right)$ might be due to their high lignin and silica contents [34].

Quantity of solid substrate taken in a container is an important parameter that needs to be optimized, since higher amount of substrate interrupts heat transfer and aeration. A high enzyme titre $\left(219.05 \pm 11.73 \mathrm{Ug}^{-1} \mathrm{DBB}\right)$ was attained when $5 / 10 \mathrm{~g}$ of substrate were taken in Erlenmeyer flasks of $250 \mathrm{~mL}$, as observed for the production of xylanase by A. niger [29]. The elevated level of substrate may hinder the optimal transfer of heat and oxygen, and thus, lead to low enzyme titre.

Salt solutions not only provide moisture to the solid substrate but also provide additional nutrients and cations to the bacterium. Various moistening agents such as tap water [35], phosphate buffer [36, 37], and salt solutions [38] have been used in SSF. A marked variation in thermo-alkali-stable pectinase production by $B$. pumilus dcsr 1 was observed when different salt solutions were used to moisten solid substrate (Figure 2). The enzyme yield was higher in salt solution 4 $\left(263 \pm 25.7 \mathrm{Ug}^{-1} \mathrm{DBB}\right)$ containing ammonium nitrate as one of its constituents than others, which might have provided an additional nitrogen source for supporting bacterial growth.

Among all culture variables, the initial moisture level is one of the most critical parameters in SSF because it determines the swelling, water tension (water surface tension), and solubility and availability of nutrients to the microbe for their growth. Moisture content of the fermentation medium determines the success of the process [29, 33]. The alkaline pectinase titre was $\left(295 \pm 12.2 \mathrm{Ug}^{-1} \mathrm{DBB}\right)$ higher when the substrate to moistening agent ratio was $1: 2.5(\mathrm{w} / \mathrm{v})$ (Figure 3). Lower enzyme titres below this ratio could be due to the reduced solubility of nutrients present in the solid substrate, a lower degree of swelling, and high water tension [39]. The production of $\alpha$-amylase by B. coagulans [28] and xylanase by $B$. licheniformis [40] was also high at this

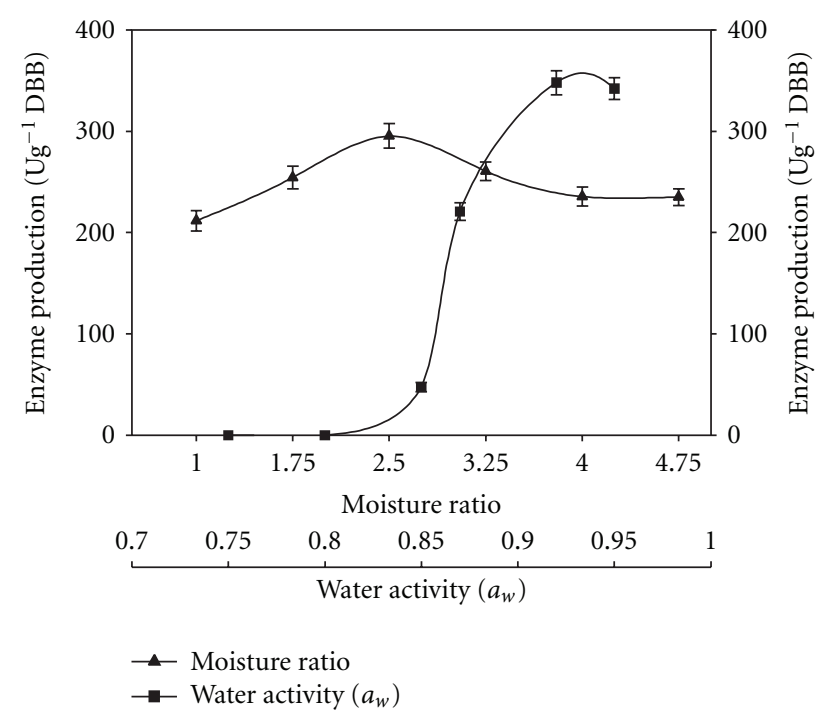

FIGURE 3: Effect of moisture level and water activity on alkaline pectinase production in SSF.

moisture level. A far lower moisture ratio ( $1: 1)$ was reported for xylanase production by Bacillus sp. A-009 [41]. The high moisture level may result in decreased porosity, changed particle structure, increased stickiness, reduced gas volume, and decreased diffusion that resulted in lower oxygen transfer and less growth.

The inoculum age and size directly affect microbial growth and enzyme production. An inoculum size of 25\% of a 24-hour-old bacterial culture supported an enzyme titre of $303 \pm 12 \mathrm{Ug}^{-1} \mathrm{DBB}$ (Figure 4). At higher inoculum levels, the production declined; this could be due to competition among bacterial cells for nutrients. The younger cultures of $B$. pumilus, being nonsporulating, entered the growth phase very soon, while the cultures older than $36 \mathrm{~h}$ produced spores which took longer time to germinate, and therefore, the enzyme production was low as previously reported [42].

The enzyme secretion by $B$. pumilus reached a peak in $120 \mathrm{~h}$ and remained constant till $144 \mathrm{~h}$, followed by a decline (Figure 5). The incubation time is the characteristics of the strain, depends on growth rate in substrate and enzyme production pattern [34]. The incubation time for SSF ranged between 30 and $144 \mathrm{~h}$ for different microbial strains [36, 37].

Pectinase titre increased when $\mathrm{pH}$ of solid substrate was increased from 4 to 9 , and thereafter, it declined (Figure 6). A maximum enzyme production was recorded at $\mathrm{pH} 9$ and $40^{\circ} \mathrm{C}$ (Figure 6). The selection of $\mathrm{pH}$ and temperature in SSF is based on the optimum $\mathrm{pH}$ and temperature for growth of microbes. The $\mathrm{pH}$ is known to act synergistically with other environmental parameters besides being a regulatory parameter in biotechnological processes [34].

Water activity $\left(a_{w}\right)$ indicates the amount of unbound water available in the surroundings of the microorganism. It is related to the water content of the substrate, although it is not equal to moisture content. The water activity $\left(a_{w}\right)$ of the substrate is important in SSF because at relatively low water availability, growth and metabolism can be limited 
TABLE 2: Effect of various treatments on the physical properties of ramie fibre.

\begin{tabular}{|c|c|c|c|c|c|c|}
\hline $\begin{array}{l}\text { Type of treatment given to } \\
\text { the fibre }\end{array}$ & $\begin{array}{l}\text { Stress at peak } \\
(\mathrm{MPa})\end{array}$ & $\begin{array}{l}\text { Young's modulus } \\
\text { (GPa) }\end{array}$ & $\begin{array}{c}\text { Strain at max. load } \\
(\%)\end{array}$ & $\begin{array}{l}\text { Brightness } \\
\quad(l)\end{array}$ & $\begin{array}{l}\text { Redness } \\
\text { (a) }\end{array}$ & $\begin{array}{c}\text { Yellowness } \\
(b)\end{array}$ \\
\hline Raw fibre (Control) & 488.94 & 23.40 & 8.571 & 108.25 & 1.48 & 8.55 \\
\hline Chemical $(12 \% \mathrm{NaOH})$ & 478.73 & 26.06 & 6.78 & 121 & 0.91 & 3.42 \\
\hline Commercial fibre & 374.1 & 13.69 & 13.21 & 115 & 1.03 & 4.75 \\
\hline Enzyme $+\mathrm{NaOH}(0.04 \%)$ & 848.6 & 25.89 & 9.93 & 118.87 & 0.98 & 4.02 \\
\hline
\end{tabular}

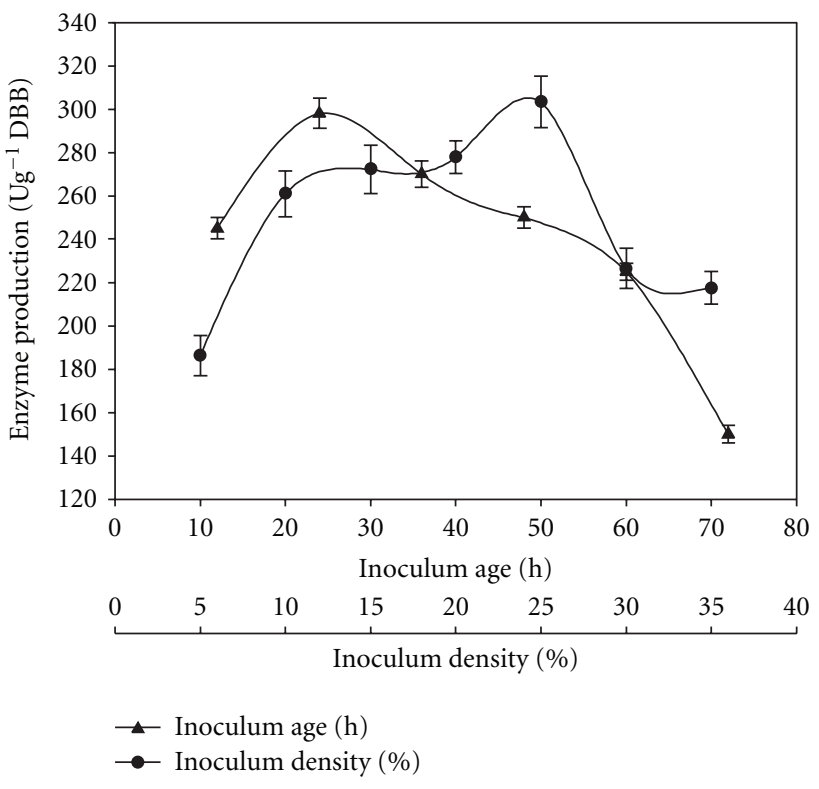

FIGURE 4: Effect of inoculum age and density on alkaline pectinase production in SSF.

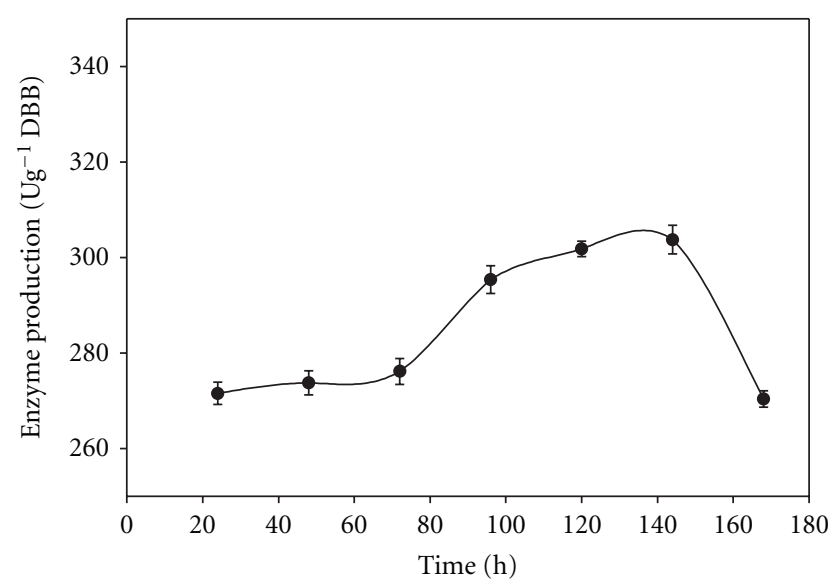

FIGURE 5: Alkaline pectinase production in SSF at various incubation periods.

[43]. The extrapolation of $a_{w}$ could be useful in modifying metabolite production or secretion of a product $[43,44]$. The production of alkaline pectinase by $B$. pumilus followed the same trend (Figure 3). The ability of bacterium to grow on solid substrate at low water activity appeared to be an adaptation of the bacterium for survival in the soil.

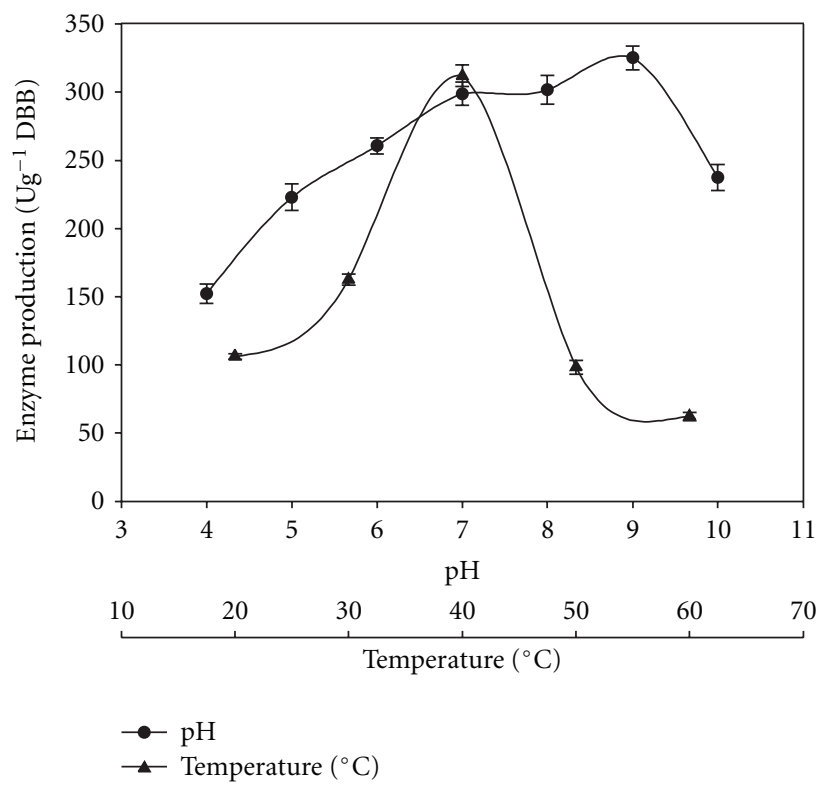

Figure 6: Effect of $\mathrm{pH}$ and temperature on enzyme production.

Parametric optimization under SSF resulted in overall 1.7-fold increase in enzyme production, while a 14.2-fold enhancement was achieved in SSF as compared to statistically optimized medium in SmF [15]. There are several reports claiming that the SSF technique yields higher enzyme titres than SmF [29, 40, 45-47], but many of them have not compared alkaline pectinase production in both processes [4, 48]. Enhancement in enzyme production in SSF as compared to that in SmF could be due to the intimate contact of the organism to the substrate and minimization of catabolite repression [17].

Ramie fibres were treated with the alkaline pectinase produced by B. pumilus dcsr1 [15] and changes in the physical properties of fibre were evaluated. The comparison of physical properties of fibre after various treatments showed significant variations (Table 2). The tensile strength and Young's Modulus of the fibre increased after combined treatment of fibres with $\mathrm{NaOH}(0.04 \%)$ followed by the enzyme $(300 \mathrm{U} / \mathrm{g}$ dry fibre), which resulted in the reduction of brittleness, redness, yellowness, and increase in the strength and brightness of the fibre. An increase in Young's Modulus in $\mathrm{NaOH}-(12 \%)$ treated fibre could be due to the deeper penetration of the enzyme and chemicals into the fibre and digestion of other polymers present on the surface. This nonspecific digestion definitely caused slight increase in elasticity 
but led to a compromise in tensile strength of the fibre. Nonspecific digestion with chemicals leads to high brightness due to the digestion of other polymers including cellulose, which was evident from the decrease in strength of the fibre.

\section{Conclusions}

The amenability of Bacillus pumilus dcsr1 to solid state fermentation and its ability to produce thermo-alkali-stable pectinase using cost-effective agro-residue were successfully established. A 14.2 fold enhancement in enzyme production was achieved in SSF in comparison with that in submerged fermentation. The enzyme has been found to be useful in the environment-friendly processing of ramie fibres without compromising the quality of treated fibres.

\section{Acknowledgments}

The authors gratefully acknowledge the financial assistance from the Ministry of Environment and Forests, Government. of India during the course of this investigation. Thier thanks are also due to Mr. Rajesh Pathania (All India Institute Medical Sciences, New Delhi, India) for his help in scanning electron microscopic studies.

\section{References}

[1] A. Pandey, W. Azmi, J. Singh, and U. C. Banerjee, "Fermentation types and factors affecting it," in Biotechnology: Food Fermentation, V. K. Joshi and A. Pandey, Eds., vol. 1, pp. 383426, Educational Publishers \& Distributers, New Delhi, India, 1999.

[2] S. A. Singh, H. Plattner, and H. Diekmann, "Exopolygalacturonate lyase from a thermophilic Bacillus sp," Enzyme and Microbial Technology, vol. 25, no. 3-5, pp. 420-425, 1999.

[3] M. M. C. N. Soares, R. Da Silva, and E. Gomes, "Screening of bacterial strains for pectinolytic activity: characterization of the polygalacturonase produced by Bacillus species," Revista de Microbiologia, vol. 30, no. 4, pp. 299-303, 1999.

[4] D. R. Kashyap, S. K. Soni, and R. Tewari, "Enhanced production of pectinase by Bacillus sp. DT7 using solid state fermentation," Bioresource Technology, vol. 88, no. 3, pp. 251254, 2003.

[5] R. A. Hours, C. E. Voget, and R. J. Ertola, "Some factors affecting pectinase production from apple pomace in solidstate cultures," Biological Wastes, vol. 24, no. 2, pp. 147-157, 1988.

[6] Y. D. Hang and E. E. Woodanms, "Production of fungal polygalactur $\neg$ onase from apple pomace," LebensmittelWissenschaft und-Technologie, vol. 27, no. 2, pp. 194-196, 1994.

[7] C. G. Garzon and R. A. Hours, "Citrus waste: an alternative substrate for pectinase production in solid-state culture," Bioresource Technology, vol. 39, no. 1, pp. 93-95, 1992.

[8] A. S. Ismail, "Utilization of orange peels for the production of multienzyme complexes by some fungal strains," Process Biochemistry, vol. 31, no. 7, pp. 645-650, 1996.

[9] D. Mamma, E. Kourtoglou, and P. Christakopoulos, "Fungal multienzyme production on industrial by-products of the citrus-processing industry," Bioresource Technology, vol. 99, no. 7, pp. 2373-2383, 2008.
[10] M. Acuna-Arguelles, M. Gutierrez-Rojas, G. ViniegraGonzalez, and E. Favela-Torres, "Effect of water activity on exo-pectinase production by Aspergillus niger $\mathrm{CH} 4$ on solid state fermentation," Biotechnology Letters, vol. 16, no. 1, pp. 23-28, 1994.

[11] D. Iandolo, A. Piscitelli, G. Sannia, and V. Faraco, "Enzyme production by solid substrate fermentation of pleurotus ostreatus and trametes versicolor on tomato pomace," Applied Biochemistry and Biotechnology, vol. 163, no. 1, pp. 40-51, 2011.

[12] Z. H. Bai, H. X. Zhang, H. Y. Qi, X. W. Peng, and B. J. Li, "Pectinase production by Aspergillus niger using wastewater in solid state fermentation for eliciting plant disease resistance," Bioresource Technology, vol. 95, no. 1, pp. 49-52, 2004.

[13] C. T. Kelly and W. M. Fogarty, "Production and properties of polygalacturonate lyase by an alkalophilic microorganism Bacillus sp. RK9," Canadian Journal of Microbiology, vol. 24, no. 10, pp. 1164-1172, 1978.

[14] T. Kobayashi, K. Koike, T. Yoshimatsu et al., "Purification and properties of a low-molecular-weight, high-alkaline pectate lyase from an alkaliphilic strain of Bacillus," Bioscience, Biotechnology and Biochemistry, vol. 63, no. 1, pp. 65-72, 1999.

[15] D. C. Sharma and T. Satyanarayana, "A marked enhancement in the production of a highly alkaline and thermostable pectinase by Bacillus pumilus dcsr1 in submerged fermentation by using statistical methods," Bioresource Technology, vol. 97, no. 5, pp. 727-733, 2006.

[16] S. Gupta, M. Kapoor, K. K. Sharma, L. M. Nair, and R. C. Kuhad, "Production and recovery of an alkaline exopolygalacturonase from Bacillus subtilis RCK under solidstate fermentation using statistical approach," Bioresource Technology, vol. 99, no. 5, pp. 937-945, 2008.

[17] G. Kaur and T. Satyanarayana, "Production of extracellular pectinolytic, cellulolytic and xylanoytic enzymes by thermophilic mould Sporotrichum thermophile Apinis in solid state fermentation," Indian Journal of Biotechnology, vol. 3, no. 4, pp. 552-557, 2004.

[18] J. Zeni, K. Cence, C. E. Grando et al., "Screening of pectinaseproducing microorganisms with polygalacturonase activity," Applied Biochemistry and Biotechnology, vol. 163, no. 3, pp. 383-392, 2011.

[19] T. Sakai, T. Sakamoto, J. Hallaert, and E. J. Vandamme, "Pectin, pectinase, and protopectinase: production, properties, and applications," Advances in Applied Microbiology, vol. 39, pp. 213-294, 1993.

[20] H. K. Sreenath, A. B. Shah, V. W. Yang, M. M. Gharia, and T. W. Jeffries, "Enzymatic polishing of jute/cotton blended fabrics," Journal of Fermentation and Bioengineering, vol. 81, no. 1, pp. 18-20, 1996.

[21] I. Reid and M. Ricard, "Pectinase in papermaking: solving retention problems in mechanical pulps bleached with hydrogen peroxide," Enzyme and Microbial Technology, vol. 26, no. 2-4, pp. 115-123, 2000.

[22] T. Tzanov, M. Calafell, G. M. Guebitz, and A. Cavaco-Paulo, "Bio-preparation of cotton fabrics," Enzyme and Microbial Technology, vol. 29, no. 6-7, pp. 357-362, 2001.

[23] G. S. Murugesan, J. Angayarkanni, and K. Swaminathan, "Effect of tea fungal enzymes on the quality of black tea," Food Chemistry, vol. 79, no. 4, pp. 411-417, 2002.

[24] S. Basu, M. N. Saha, D. Chattopadhyay, and K. Chakrabarti, "Large-scale degumming of ramie fibre using a newly isolated Bacillus pumilus DKS1 with high pectate lyase activity," Journal of Industrial Microbiology and Biotechnology, vol. 36, no. 2, pp. 239-245, 2009. 
[25] F. Bruhlmann, K. S. Kim, W. Zimmerman, and A. Fiechter, "Pectinolytic enzymes from actinomycetes for the degumming of ramie bast fibers," Applied and Environmental Microbiology, vol. 60, no. 6, pp. 2107-2112, 1994.

[26] D. Crônier, B. Monties, and B. Chabbert, "Structure and chemical composition of bast fibers isolated from developing hemp stem," Journal of Agricultural and Food Chemistry, vol. 53, no. 21, pp. 8279-8289, 2005.

[27] W. Grajek and P. Gervais, "Influence of water activity on the enzyme biosynthesis and enzyme activities produced by Trichoderma viride TS in solid-state fermentation," Enzyme and Microbial Technology, vol. 9, no. 11, pp. 658-662, 1987.

[28] K. R. Babu and T. Satyanarayana, "alpha-Amylase production by thermophilic Bacillus coagulans in solid state fermentation," Process Biochemistry, vol. 30, no. 4, pp. 305-309, 1995.

[29] Y. S. Park, S. W. Kang, J. S. Lee, S. L. Hong, and S. W. Kim, "Xylanase production in solid state fermentation by Aspergillus niger mutant using statistical experimental designs," Applied Microbiology and Biotechnology, vol. 58, no. 6, pp. 761-766, 2002.

[30] A. Pandey, P. Nigam, C. R. Soccol, V. T. Soccol, D. Singh, and R. Mohan, "Advances in microbial amylases," Biotechnology and Applied Biochemistry, vol. 31, no. 2, pp. 135-152, 2000.

[31] V. F. Soares, L. R. Castilho, E. P. S. Bon, and D. M. G. Freire, "High-yield Bacillus subtilis protease production by solid-state fermentation," Applied Biochemistry and Biotechnology A, vol. 121, no. 1-3, pp. 311-319, 2005.

[32] M. V. Ramana Murthy, N. G. Karnath, and K. S. M. S. RaghavaRao, "Biochemical engineering aspects of solid state fermentation," Advances in Applied Microbiolog, vol. 38, pp. 99-147, 1993.

[33] B. K. Lonsane, N. P. Childyal, S. Budiatman, and S. V. Ramakrishna, "Engineering aspects of solid state fermentation," Enzyme and Microbial Technology, vol. 7, no. 6, pp. 258265, 1985.

[34] M. V. Ramesh and B. K. Lonsane, "Production of bacterial thermostable $\alpha$-amylase by solid-state fermentation: a potential tool for achieving economy in enzyme production and starch hydrolysis," Advances in Applied Microbiology, vol. 35, pp. 1-56, 1990.

[35] S. A. Jaleel, S. Srikanta, and N. G. Karnath, "Production of fungal amyloglucosidase by solid state fermentation-influence of some parameters," Journal of Microbiology and Biotechnology, vol. 7, pp. 1-8, 1992.

[36] M. V. Ramesh and B. K. Lonsane, "A novel bacterial thermostable alpha-amylase system produced under solid state fermentation," Biotechnology Letters, vol. 9, no. 7, pp. 501-504, 1987.

[37] M. V. Ramesh and B. K. Lonsane, "Solid state fermentation for production of $\alpha$-amylase by Bacillus megaterium 16M," Biotechnology Letters, vol. 9, no. 5, pp. 323-328, 1987.

[38] Y. K. Park and B. C. Rivera, "Alcohol production from various enzyme converted starches with or without cooking," Biotechnology and Bioengineering, vol. 24, no. 2, pp. 495-500, 1982.

[39] F. Zadrazil and H. Brunnert, "Investigation of physical parameters important for the solid state fermentation of straw by white rot fungi," European Journal of Applied Microbiology and Biotechnology, vol. 11, no. 3, pp. 183-188, 1981.

[40] A. Archana and T. Satyanarayana, "Xylanase production by thermophilic Bacillus licheniformis A99 in solid-state fermentation," Enzyme and Microbial Technology, vol. 21, no. 1, pp. 12-17, 1997.
[41] A. Gessesse and G. Mamo, "High-level xylanase production by an alkaliphilic Bacillus sp. by using solid-state fermentation," Enzyme and Microbial Technology, vol. 25, no. 1-2, pp. 68-72, 1999.

[42] C. Krishna, "Solid-state fermentation systems-an overview," Critical Reviews in Biotechnology, vol. 25, no. 1-2, pp. 1-30, 2005.

[43] A. Pandey, L. Ashakumary, P. Selvakumar, and K. S. Vijayalakshmi, "Influence of water activity on growth and activity of Aspergillus niger for glycoamylase production in solid-state fermentation," World Journal of Microbiology and Biotechnology, vol. 10, no. 4, pp. 485-486, 1994.

[44] S. Xavier and N. G. Karanth, "A convenient method to measure water activity in solid state fermentation systems," Letters in Applied Microbiology, vol. 15, no. 2, pp. 53-55, 1992.

[45] S. Solis-Pereira, E. Favela-Torres, G. Viniegra-Gonzalez, and M. Gutierrez-Rojas, "Effects of different carbon sources on the synthesis of pectinase by Aspergillus niger in submerged and solid state fermentations," Applied Microbiology and Biotechnology, vol. 39, no. 1, pp. 36-41, 1993.

[46] G. Viniegra-González, E. Favela-Torres, C. N. Aguilar, S. D. J. Rómero-Gomez, G. Díaz-Godínez, and C. Augur, "Advantages of fungal enzyme production in solid state over liquid fermentation systems," Biochemical Engineering Journal, vol. 13, no. 2-3, pp. 157-167, 2003.

[47] C. Sandhya, A. Sumantha, G. Szakacs, and A. Pandey, "Comparative evaluation of neutral protease production by Aspergillus oryzae in submerged and solid-state fermentation," Process Biochemistry, vol. 40, no. 8, pp. 2689-2694, 2005.

[48] D. Salariato, L. A. Diorio, N. Mouso, and F. Forchiassin, "Extraction and characterization of polygalacturonase of fomes sclerodermeus produced by solid-state fermentation," Revista Argentina de Microbiologia, vol. 42, no. 1, pp. 57-62, 2010. 

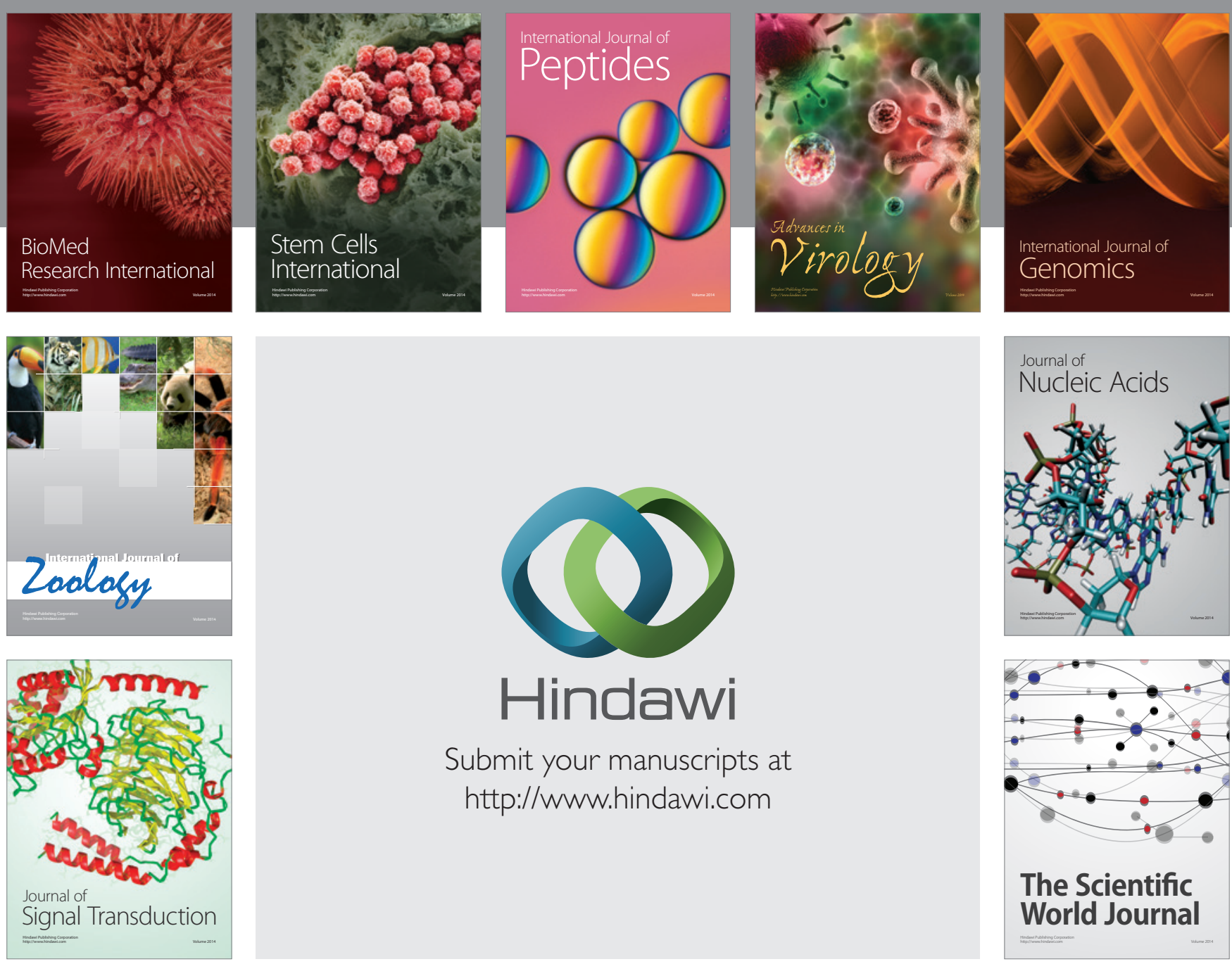

Submit your manuscripts at

http://www.hindawi.com
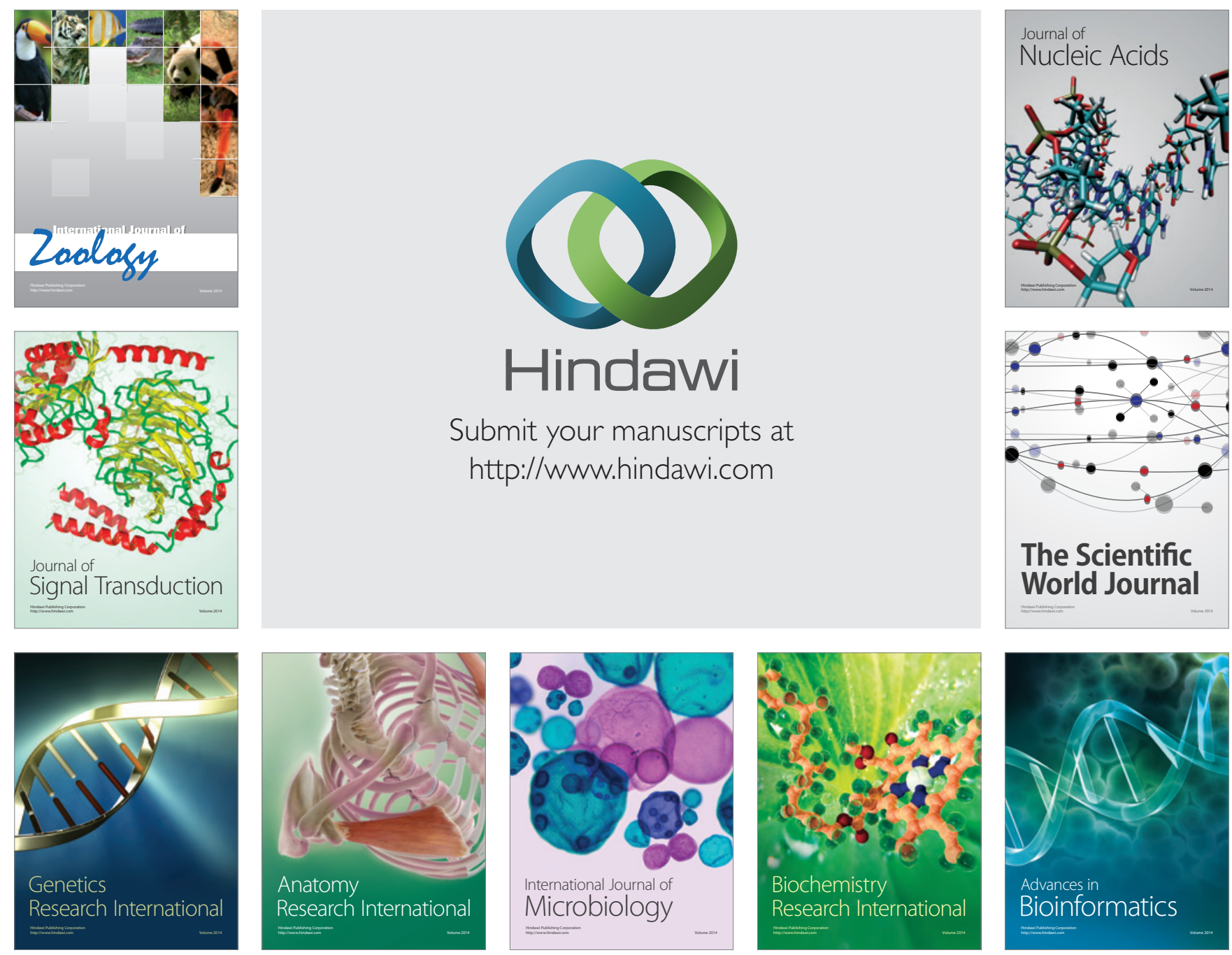

The Scientific World Journal
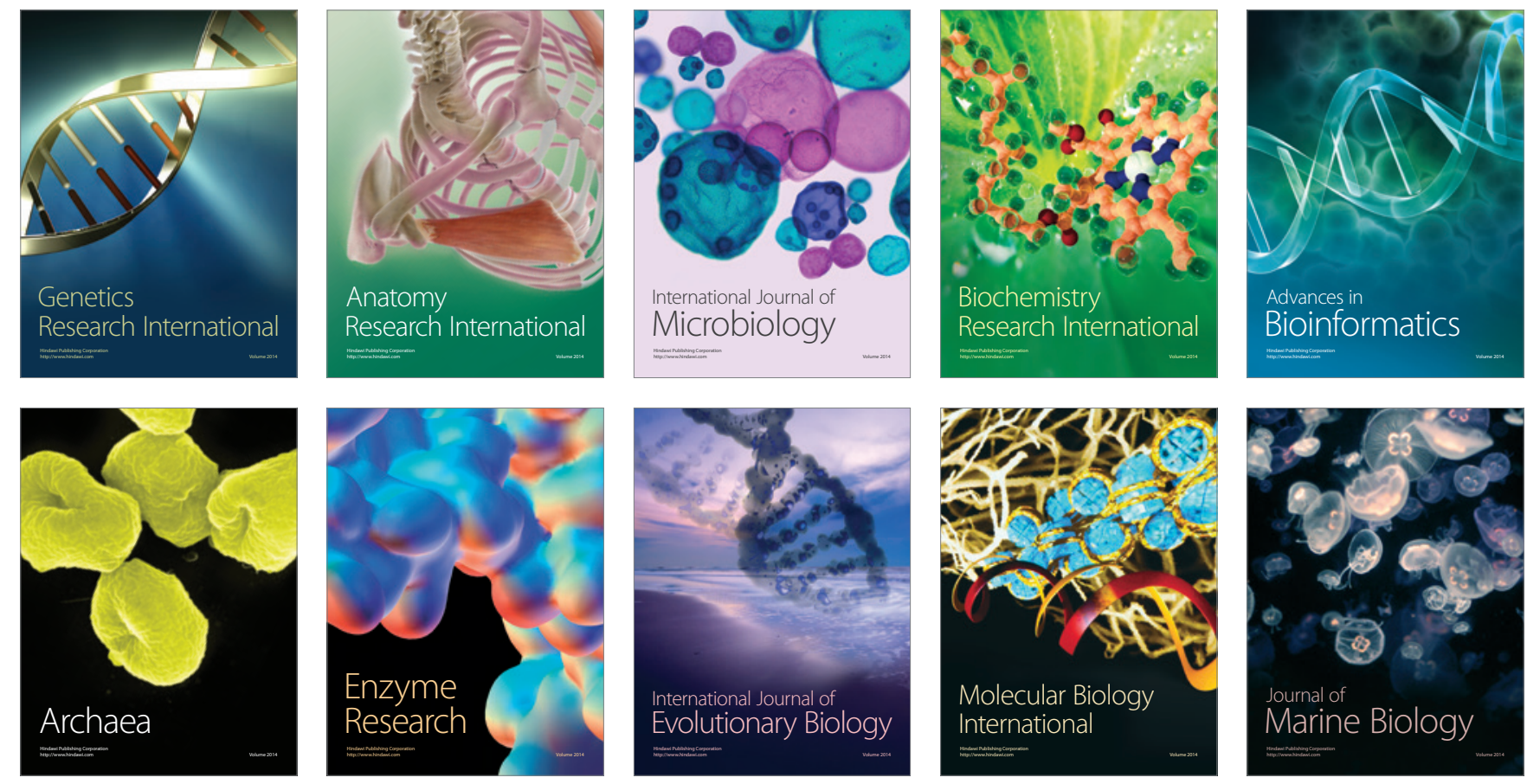